\title{
Immediate iliac bone graft reconstruction of post ablative defect of benign mandibular pathology - a systematic review
}

\author{
Olufemi K. Ogundipe', Olalere O. Gbolahan ${ }^{2}$ \\ ${ }^{1}$ Department of Oral and Maxillofacial Surgery and Oral Pathology, Obafemi Awolowo University, Ile-Ife 220005, Nigeria. \\ ${ }^{2}$ Department of Oral and Maxillofacial Surgery, University of Ibadan/University College Hospital, Ibadan 220284, Nigeria.
}

Correspondence to: Dr. Olufemi K. Ogundipe, Department of Oral and Maxillofacial Surgery and Oral Pathology, Obafemi Awolowo University, Ile-Ife 220005, Nigeria. E-mail: olufemikola@yahoo.co.uk

How to cite this article: Ogundipe OK, Gbolahan OO. Immediate iliac bone graft reconstruction of post ablative defect of benign mandibular pathology - a systematic review. Plast Aesthet Res 2017;4:137-43.

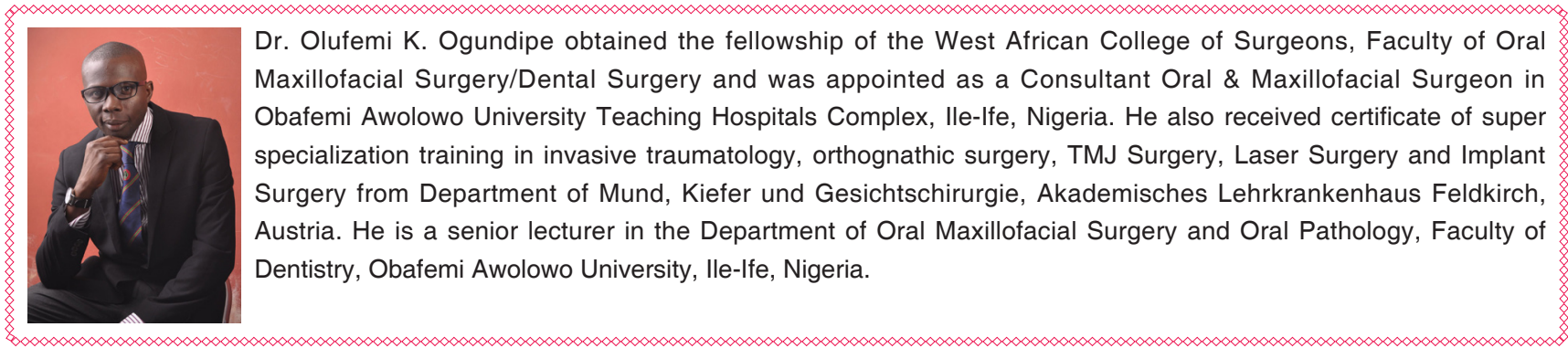

Article history:

Received: $31-05-2017$

Accepted: 22-08-2017

Published: 29-08-2017

Key words:

Benign pathology,

mandibular reconstruction,

bone graft,

iliac crest,

non-vascularized,

immediate reconstruction

\begin{abstract}
Aim: Autogenous iliac crest bone graft is frequently used in immediate reconstruction of post ablation defect of benign mandibular pathologies. The aim of this study was to conduct a systematic literature review on the complication and failure rates with this technique and factors associated with failure. Methods: The initial literature search in PubMed and Cochrane databases identified 915 articles. Result: Of these, 7 were included in the final review. The majority of the studies were retrospective in nature. These articles encompassed 127 procedures with non-vascularized iliac crest bone graft; with complication rate of $13.3 \%$ and failure rate of $3.1 \%$, most complications did not result in failure. All failures were due to infection with no main factor associated with failure. Conclusion: Use of non-vascularized iliac crest bone graft for immediate mandibular reconstruction appears to be associated with low complication and failure rates in carefully selected cases.
\end{abstract}

cc) (1) 5 This is an open access article distributed under the terms of the Creative Commons AttributioncC) $\mathrm{BY}$ NC SA NonCommercial-ShareAlike 3.0 License, which allows others to remix, tweak, and build upon the work non-commercially, as long as the author is credited and the new creations are licensed under the identical terms.

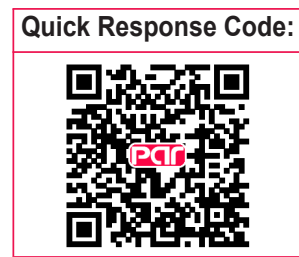




\section{INTRODUCTION}

Mandibular defects resulting from tumor ablation often result in considerable challenges to the patient and the surgeon. ${ }^{[1,2]}$ On the part of the patient there is varying degree of functional, aesthetic and psychosocial challenges which may severely affect the quality of life of the patient. On the part of the surgeon the challenge is that of reconstruction to restore the normal anatomic form and function of the mandible. ${ }^{[3,4]}$ Various reconstructive options that have been documented in published literature include autograft, xenograft and alloplast. ${ }^{[4-6]}$ Newer options like genetically engineered bone and distraction osteogenesis are also getting more attention among surgeons as novel options for mandibular reconstruction. ${ }^{[7-10]}$

Use of alloplast as bridging plates may have the advantage of ease of placement, maintenance of shape over time, lack of donor site morbidity, satisfactory aesthetic outcome in the immediate post operative period but the draw back is in the long term performance due to the risk of hardware rejection, fracture, plate extrusion and limitation in use of dental implants. A failure rate of $60-80 \%$ for alloplastic material has been documented in the literature. ${ }^{[3]}$

Newer options like genetically engineered bone are still in the early stage of development, needs expensive equipment, expertise and are not widely available yet. ${ }^{[0]}$

At present, autogenous graft (vascularized or non vascularized) remains the most popular means of reconstructing continuity mandibular defect having the best chance of take as they provide viable and immune compatible osteogenic cells. ${ }^{[11,12]}$

The main aim of mandibular reconstruction following ablative surgery is the restoration of form and function usually achieved by autogenous bone grafts (ABG). ${ }^{[13,14]}$ Different sites of the body are available for harvesting the graft, however, the choice of a particular donor site depends on factors such as the type and extent of tissue defect, rehabilitation expectation of the patient, condition of the recipient bed, availability of necessary equipment and expertise of the surgeon. ${ }^{[2,13-15]} A B G$ options include vascularized and non vascularized grafts. The major limitation of non-vascularized bone graft (NVBG) lies in the fact that it is avascular making it susceptible to infection thereby increasing the chances of failure with increasing length of the defect. Also defective intra-oral soft tissue cover for the graft following tumor ablation exposes the NVBG to the risk of failure from saliva microbial contamination and subsequent infection. Vascularized bone graft
(VBG) overcomes these shortcomings by virtue of its inherent own vascularity and can also be harvested with soft tissue for cover and lining in situations where there is defective soft tissue at the recipient site. This explains the increased popularity of vascularized bone graft which is fast becoming the standard of care in reconstruction of mandibular continuity defect among many surgeons in developed nations. However it also has a number of disadvantages like longer length of surgery, expensive equipment and expertise..$^{[2,13-15]}$

NVBG still remains an attractive and viable option in mandibular reconstruction in many parts of the world especially in developing countries where there is no facility or expertise for microvascular anastomosis. This traditional technique for the reconstruction of the mandible is indicated mainly to bridge segmental defects of the mandible where adjuvant radiotherapy is not indicated after ablative surgery. ${ }^{[16]}$ Possible donor sites for NVBG include the calvarium, ilium, rib, scapula, clavicle and fibula. ${ }^{[3,17]}$ However the ilium remains the workhorse with most authors due to its relative advantages like ease of harvest, good osseous bulk, contour, favorable bio-mechanics and sufficient width for implant placement. ${ }^{[17,18]}$ Despite its relative advantages, varied complication/failure rate have been reported with non-vascularized iliac crest bone graft (NVICBG) while controversies remain about the ideal timing for the reconstruction. ${ }^{[3,18,19]}$ Immediate reconstruction is highly desirable and could potentially eliminate the shortcomings of delayed procedure such as functional and aesthetic limitation leading to reduced quality of life. Furthermore, the high failure rate previously cited ${ }^{[20,21]}$ with immediate NVICBG has been countered by other authors who opined that failure may be connected with inappropriate patient selection and sub-optimal method of treatment. ${ }^{[22,23]}$ The aim of this review was to conduct a systematic literature review on the complication and failure rates of use of NVICBG and factors associated with failure.

\section{METHODS}

\section{Literature search}

We searched the PubMed, Medline and Cochrane databases using the terms "mandibular reconstruction" AND "autogenous bone graft" to retrieve all relevant articles. The search was restricted to human studies published in English. In addition, the "related articles" options in PubMed Medline and manual search of bibliographies of identified articles were used to retrieve additional studies.

\section{Criteria for eligibility}

Studies were included if they reported on success/ 


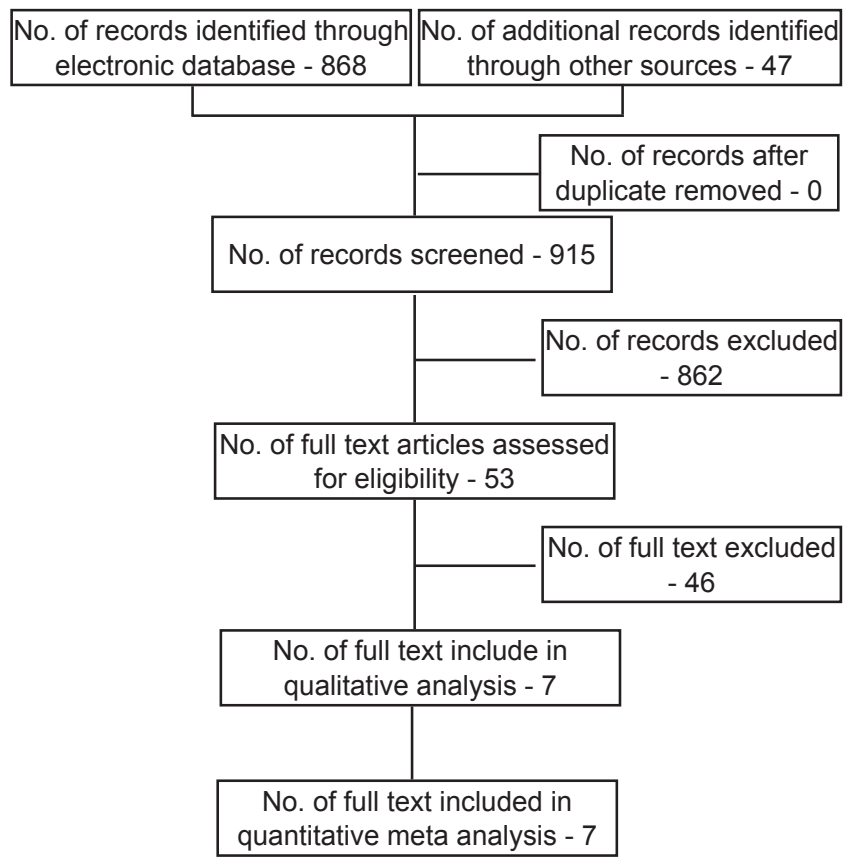

Figure 1: Flow chart

failure of immediate mandibular reconstruction of post ablative continuity defect of benign pathology using NVICBG.

Articles that referred to infants or patients treated with radiation, had a diagnosis of malignancy, were being grafted for reasons other than benign pathology and those that did not report a follow up of at least six months were excluded. Reviews and case reports of a single case were not included. The title and abstract of the identified articles were screened based on these criteria after which the full text of all eligible articles were retrieved for further analysis.

\section{Extraction of data}

A proforma was used to extract data from the eligible articles. Information extracted included primary author, year of publication, study type, age and number of patients, method of fixation, follow up, and documented complication and failure. Extent of defect was classified as segmental and hemi-mandibulectomy defect.

For this review, recipient site complication was counted as per patient irrespective of the number. Failure is defined as inability to control infection necessitating graft loss or removal. Whenever possible, factors associated with failure were identified.

\section{Statistical analysis}

Descriptive statistics was used for analysis. The characteristics of the included publications were summarized and presented in tables.

\section{RESULTS}

Initial elecronic searches of MEDLINE and Cochrane retrieved 868 articles as potentially eligible, 47 publications were identified from other sources. After initial review of the titles and abstracts, 53 articles were accepted for further consideration, and 862 were rejected [Figure 1]. Of the 53 articles accepted for further consideration, 46 were excluded because they did not meet the inclusion criteria which left 7 fulltext articles for further consideration and analysis. Of the 7 included articles reviewed, all were retrospective cohort studies except 2 which were prospective longitudinal studies.

A total of 127 patients treated with NVBG were included in this review. Gender characteristics were reported in all the articles with slight female preponderance (female 65/127, 51.2\%; male 62/127, 48.8\%). Age was reported as mean in all publications ranging 24.631.6 years. Table 1 shows the study characteristics of the publications. All the articles reviewed except one reported the histologic diagnosis of the lesions for which mandibular resection was carried out. Majority of the lesions were ameloblastoma - 80 $(74.8 \%)$, followed by ossifying fibroma - 9 (8.4\%) [Table 2]. Segmental mandibulectomy was done in 100 patients $(78.7 \%)$ while the remaining $27(21.3 \%)$ had hemi-mandibulectomy. Both intra and extra oral incisions were utilized in 100 patients $(78.7 \%)$ with the remaining $27(21.3 \%)$ receiving only intra oral incision. Reconstruction plate was the method of fixation in the majority $87 / 127(68.5 \%)$ while stainless steel wire/intermaxillary fixation was used in the remaining 40/127 (31.5\%). Autologous platelet rich plasma was used as graft enhancement in 32/127 patients. The follow up period was presented as means, of which the highest was 7 years and lowest was 6 months.

Recipient site complications such as infection, wound dehiscence, etc. were reported in 16/120 [Table 3] patients giving a complication rate of $13.3 \%$. The case series did not clearly report complication in the 7 cases presented however none of the cases failed as at last review. Overall failure rate was $4 / 127$ or $3.1 \%$. Of the 4 cases that failed, 2 were reported by 1 publication while 1 each was reported by other 2 . All failures were due to uncontrollable infection, 2 occurred in hemimandibulectomy defect while the remaining 2 occurred in segmental defect. One of the failed reconstruction had been enhanced with platelet rich plasma (PRP). Age, gender, type of incision and method of fixation did not appear to affect failure rate.

Only 22 patients (10 implants and 12 acrylic partial dentures) received prosthesis following reconstruction. 
Table 1: Study characteristics of publications reviewed

\begin{tabular}{|c|c|c|c|c|c|c|c|c|c|c|c|c|c|}
\hline $\begin{array}{l}\text { Author/ } \\
\text { year }\end{array}$ & $\begin{array}{c}\text { Journal } \\
\text { name }\end{array}$ & $\begin{array}{l}\text { Type of } \\
\text { study }\end{array}$ & $\begin{array}{c}\text { No. of } \\
\text { patient }\end{array}$ & $M / F$ & $\begin{array}{l}\text { Mean } \\
\text { age } \\
\text { (years) }\end{array}$ & Incision & $\begin{array}{c}\text { Type of defect, } \\
\text { segmental/ } \\
\text { hemimandible }\end{array}$ & $\begin{array}{l}\text { Method } \\
\text { of } \\
\text { fixation }\end{array}$ & $\begin{array}{c}\text { Graft } \\
\text { enhancement, } \\
\text { yes/no }\end{array}$ & $\begin{array}{l}\text { Mean } \\
\text { follow-up } \\
\text { (months) }\end{array}$ & Complication & Failure & Prosthesis \\
\hline $\begin{array}{l}\text { Obiechina } \\
\text { et al. }{ }^{[25]} \\
/ 2003\end{array}$ & $\begin{array}{l}\text { West Afr J } \\
\text { Med }\end{array}$ & $\begin{array}{l}\text { Retrospective } \\
\text { cohort }\end{array}$ & 20 & $14 / 6$ & 25.5 & $\begin{array}{l}\text { Intra oral/ } \\
\text { extra oral }\end{array}$ & $15 / 5$ & $\begin{array}{l}\text { SS wire/ } \\
\text { IMF }\end{array}$ & No & $13(2-25)$ & 1 & 1 & None \\
\hline $\begin{array}{l}\text { Shirani } \\
\text { et al. }{ }^{[30]} \\
12007\end{array}$ & $\begin{array}{l}\text { J } \\
\text { Craniofac } \\
\text { Surg }\end{array}$ & $\begin{array}{l}\text { Retrospective } \\
\text { case series }\end{array}$ & 7 & $4 / 3$ & 24.6 & Intra oral & $7 / 0$ & $\begin{array}{l}\text { Recons } \\
\text { plate }\end{array}$ & No & $24.4(7-60)$ & Not stated & 0 & None \\
\hline $\begin{array}{l}\text { Agrawal } \\
\text { et al. }{ }^{[3]} \\
\text { / } 2012\end{array}$ & $\begin{array}{l}\text { J Oral } \\
\text { Biology } \\
\text { Craniofac } \\
\text { Res }\end{array}$ & Prospective & 10 & $3 / 7$ & 26.9 & $\begin{array}{l}\text { Intra oral/ } \\
\text { extra oral }\end{array}$ & $7 / 3$ & $\begin{array}{l}\text { Recons } \\
\text { plate }\end{array}$ & No & $6(0-6)$ & 3 & 0 & None \\
\hline $\begin{array}{l}\text { Simon } \\
\text { et al. } \\
12013\end{array}$ & $\begin{array}{l}\text { Int J Oral } \\
\text { Maxillofac } \\
\text { Surg }\end{array}$ & $\begin{array}{c}\text { Retrospective } \\
\text { cohort }\end{array}$ & 32 & $11 / 21$ & 27.7 & $\begin{array}{l}\text { Intra oral/ } \\
\text { extra oral }\end{array}$ & $32 / 0$ & $\begin{array}{l}\text { Recons } \\
\text { plate }\end{array}$ & Yes (prp) & $27.9(6-84)$ & 3 & 1 & $\begin{array}{l}\text { Acrylic } \\
\text { PD/12 }\end{array}$ \\
\hline $\begin{array}{l}\text { Olusanya } \\
\text { et al. }{ }^{[19]} \\
\text { /2014 }\end{array}$ & Nig Med J & Prospective & 20 & $8 / 12$ & 31.6 & $\begin{array}{l}\text { Intra oral/ } \\
\text { extra oral }\end{array}$ & $11 / 9$ & $\begin{array}{l}\text { SS wire/ } \\
\text { IMF }\end{array}$ & No & $24(0-24)$ & 4 & 0 & None \\
\hline $\begin{array}{l}\text { Schlieve } \\
\text { et al. }{ }^{[23]} \\
\text { /2015 }\end{array}$ & $\begin{array}{l}\text { J Oral } \\
\text { Maxillofac } \\
\text { Surg }\end{array}$ & $\begin{array}{l}\text { Retrospective } \\
\text { cohort }\end{array}$ & 20 & $11 / 9$ & 28.3 & Intra oral & $20 / 0$ & $\begin{array}{l}\text { Recons } \\
\text { plate }\end{array}$ & No & $22(6-61)$ & 2 & 0 & Implant/10 \\
\hline $\begin{array}{l}\text { Okoturo }^{[28]} \\
\text { /2016 }\end{array}$ & $\begin{array}{l}\text { Oral } \\
\text { Maxillofac } \\
\text { Surg }\end{array}$ & $\begin{array}{l}\text { Retrospective } \\
\text { cohort }\end{array}$ & 18 & $11 / 7$ & 29.4 & $\begin{array}{l}\text { Intra oral/ } \\
\text { extra oral }\end{array}$ & $8 / 10$ & $\begin{array}{l}\text { Recons } \\
\text { plate }\end{array}$ & No & $13.5(5-22)$ & 3 & 2 & None \\
\hline
\end{tabular}

Table 2: Histologic diagnoses per author

\begin{tabular}{|c|c|c|}
\hline Histologic diagnosis & No. of cases per author & $n(\%)$ \\
\hline Ameloblastoma & $\begin{array}{l}\text { Simon et al } l^{[29]}-(32) \text {, Okoturo }{ }^{[28]}-(10), \text { Schlieve et al }{ }^{[23]}-(13) \text {, Shirani et al } .^{[30]}-(4) \text {, } \\
\text { Obiechina et al }{ }^{[25]}-(13) \text {, Agrawal et al. }{ }^{[3]}-(8)\end{array}$ & $80(74.8)$ \\
\hline Ossifying fibroma & Okoturo ${ }^{[28]}$ - (4), Schlieve et al. ${ }^{[23]}$ - (2), Obiechina et al. $.^{[25]}-(3)$ & $9(8.4)$ \\
\hline Odontogenic myxoma/fibromyxoma & Schlieve et al. ${ }^{[23]}-(2)$, Okoturo ${ }^{[28]}-(2)$, Obiechina et al. ${ }^{[25]}-(2)$, Shirani et al. ${ }^{[30]}$ - (1) & $7(6.5)$ \\
\hline Odontogenic keratocyst & Shirani et al. $.^{[30]}-(1)$, Agrawal et al. $.^{[3]}-(1)$ & $2(1.9)$ \\
\hline Ameloblastic fibroma & Obiechina et al. ${ }^{[25]}-(2)$ & $2(1.9)$ \\
\hline Cementoblastoma & Schlieve et al. $^{[23]}-(1)$ & $1(0.9)$ \\
\hline Odontogenic cyst & Okoturo $^{[28]}-(1)$ & $1(0.9)$ \\
\hline Central giant cell granuloma & Okoturo $^{[28]}-(1)$ & $1(0.9)$ \\
\hline Spindle cell tumor & Shirani et al ${ }^{[30]}-(1)$ & $1(0.9)$ \\
\hline Arteriovenous malformation & Schlieve et al. ${ }^{[23]}-(1)$ & $1(0.9)$ \\
\hline Osteoblastoma & Schlieve et al. ${ }^{[23]}-(1)$ & $1(0.9)$ \\
\hline Osteomyelitis & Agrawal et al. ${ }^{[3]}-(1)$ & $1(0.9)$ \\
\hline Total & & $107(100)$ \\
\hline
\end{tabular}

Table 3: Types of recipient site complication

\begin{tabular}{|c|c|c|}
\hline Type of complication & $n(\%)$ & Complication per author \\
\hline Wound infection & $10(62.5)$ & $\begin{array}{l}\text { Schlieve et al. } .^{[23]}-(2), \\
\text { Obiechina et al. }{ }^{[25]}-(1) \text {, } \\
\text { Agrawal et al. }{ }^{[3]}-(3), \\
\text { Simon et al. } .^{[29]}-(2) \\
\text { Olusanya et al. } .^{[19]}-(2)\end{array}$ \\
\hline Wound dehiscence & $5(31.3)$ & $\begin{array}{c}\text { Okoturo }{ }^{[28]}-(2) \\
\text { Agrawal et al. } \\
\text { Olusanya et }{ }^{[3]} .^{[19]}-(1) \\
\text { (2) }\end{array}$ \\
\hline Orocutaneous fistulation & $1(6.2)$ & Okoturo $^{[28]}-(1)$ \\
\hline Total & $16(100)$ & \\
\hline
\end{tabular}

\section{DISCUSSION}

The present review provides the largest data yet on the outcome of NVICBG in immediate mandibular reconstruction. The review was limited to post ablative defect of benign mandibular pathologies to rule out inappropriate patient selection as a cause of failure.
Notwithstanding the retrospective nature of majority of the publications reviewed, strict inclusion and exclusion criteria used enabled us to identify only studies able to answer the research question. However, recall bias associated with retrospective reports have to be borne in mind although the authors made every effort to deduce the most appropriate information.

There is no consensus from this review on the definition of success as various authors used different criteria. Schlieve et al. ${ }^{[23]}$ defined success as provision of enough bulk to support implant placement. It should however be remembered that not all patients will prefer this additional treatment and definition of success should align with the aim of restoration which is to restore form and function.

Some authors believe that the method of immobilization has a big role to play in the success of the graft, ${ }^{[23-25]}$ 
citing the risk of micro-movement in non rigid immobilization jeopardizing the viability of the graft,, ${ }^{[25]}$ Although a number of the studies in this review employed rigid fixation of the graft with the use of plates and the authors claiming it as one of the main factors for graft success. Few of the studies due to non-affordability of plates by patients employed the use of stainless steel wires for immobilization with good outcomes even in long defect spans. ${ }^{[26]}$ However Olusanya et al. ${ }^{[19]}$ employing use of wires for immobilization reported progressive and significant deviation and resorption in the central region with alteration in the initial aesthetic contour obtained during a one year review period. This complication was absent in their patients that had reconstruction of lateral defect. ${ }^{[19]}$ On the contrary, Agrawal et al..$^{[3]}$ and Futran et al. ${ }^{[27]}$ employing rigid plate fixation reported progressive improvement in aesthetics with no report of gross resorption noted. Okoturo ${ }^{[28]}$ did not employ NVIBG for central defect (defect spanning between 33 and 43 i.e. C classification), the only two graft failure were; one that had anterior component with the lateral component (excluding the condyle) (LC) and another one that had anterior component with hemimandibulectomy component $(\mathrm{HC})$ claiming that non vascular grafts do not perform well in this region and should be reconstructed with a flap.

Compressive, tensile and torsional forces are present in the symphyseal part of the mandible which places significant stress on any construct placed in this region. These forces may exert excessive pressure on the graft which may lead to rapid resorption and even loss of the graft. Rigid reconstruction plate may help to shield the graft from these forces and may explain the progressive significant resorption noted in patients where wire was used for graft immobilization as against those with plate immobilization in the central mandibular region.

A number of authors favor extra oral approach during the procedure of reconstruction with non vascularized graft predicating their decision on avoidance of contamination of graft site with saliva leading to infection and high failure rate.

Majority of the authors in this review employed a combined intra and extra-oral approach. ${ }^{[6,19,26,28,29]}$ However, Schlieve et al. ${ }^{[23]}$ and Shirani et al. ${ }^{[30]}$ employed transoral approach with no record of graft loss among all their study population. Adequate (water tight, tension free) wound closure as well as method of fixation was cited as important factors that contributed to the success. They claimed that despite the potential risk of contamination of the graft by saliva, grafts are still able to perform well and survive in contaminated environments if rigid fixation is achieved. The high failure rate encountered by earlier authors was largely blamed on contamination with saliva and subsequently led to the popularity of delayed reconstruction to allow for use of extra-oral route. This view is now being challenged by recent research and factors other than saliva contamination including research design of those earlier work are being suggested to be responsible for the high failure rate noted in earlier works. ${ }^{[23]}$ Other works in the literature have also reported good outcome of grafts in contaminated environment when good immobilization was ensured. ${ }^{[29]}$ This view is supported by the results in the present review in which majority of the procedures that initially presented with signs of infection eventually survived, with only few resulting in graft loss from the uncontrolled infection. It has also been argued that several intra-oral bone grafting procedures are carried out with saliva contamination and most times without water tight closure including bone grafting procedures in implantology and periodontology with low failure rates recorded. ${ }^{[23]}$ As opined by Schlieve et al.,, ${ }^{[23]}$ bone grafting in the presence of contamination is possible and this brings to question the fear of oral contamination during grafting procedures.

Several published literature have reported significant association between length of defect and graft failure. ${ }^{[24]}$ Different authors have cited different lengths at which use of non vascularized bone is significantly associated with complication. Pogrel et al. ${ }^{[14]}$ cited a graft length of $9 \mathrm{~cm}$, more recent work have cited even shorter lengths of between $5-6 \mathrm{~cm}$ suggesting that NVBG should only be employed in defect size less than this cut-off. ${ }^{[2,31,32]}$ In the present review, Agrawal et al. ${ }^{[3]}$ also noted significant association between length of defect and complication. They reported a mean defect length of 9.0 in those with complication compared with 7.0 in those without complication. ${ }^{[3]}$ On the contrary, another study in the present review found no significant association between defect size and complication. ${ }^{[23]}$ Although the defect size in their series ranged between $3-10 \mathrm{~cm}$ which is much outside the cut off of $5-6 \mathrm{~cm}$ suggested by earlier authors, no complication was associated with length of defect. ${ }^{[23]}$ Obiechina et al. ${ }^{[26]}$ also reported no significant association between graft length and graft failure. Part of their series involved grafting the hemi-mandible spanning the symphysis to the ramus, only one graft failure lost to infection was recorded although it was not stated whether it was one of the long span grafts. ${ }^{[26]}$ Some authors have suggested that intra-oral approach alone resulted in better outcome of grafting because there was less disruption of soft tissue/periosteal envelope as well as less disruption of 
vascular supply to the host tissue from multiple incisions required for the combined approach. ${ }^{[23,32]}$

PRP was used in one of the studies in this review and the authors claimed that it was one of the possible factors responsible for the high success rate obtained in their study. ${ }^{[32]}$ Previous studies have also claimed the enhancement of PRP on bone healing although animal studies have failed to demonstrate unequivocally the beneficial effect of PRP on bone healing. ${ }^{[3-37]}$ On the other hand, other studies in the review got comparable or even better result despite not utilizing PRP. ${ }^{[23,26]}$ Therefore it may be difficult to ascribe the outcome to any beneficial effect of PRP as claimed by the authors. A well-designed randomized control trial may be needed to clarify any possible effect of PRP on graft success.

Factors previously identified as determinant of outcome such as age, gender, histologic type, type of incision and method of fixation did not appear to be associated with failure or success of bone grafting in this review.

The complication rate and failure rate are low suggesting that in selected cases with appropriate surgical resection margins, NVICBG done as a primary procedure is an attractive option especially in resource scarce nations. It saves the patients the cost of a second surgery and as the ablation and graft harvesting can be done simultaneously, duration of procedure does not have to be extended. Immediate reconstruction also has the advantage of better chance of achieving the desired restoration of form and function following reconstruction. Maintenance of normal spatial relationship of soft and hard tissue is key in achieving the normal form and function following reconstruction. ${ }^{[22]}$ Fibrosis following healing of initial surgery could make any desired surgical alteration in tissue positioning at subsequent surgery quite difficult if not impossible once the tissues have been fixed in a less optimal position. Subsequent dental rehabilitation and aesthetic outcome may then be severely hampered. ${ }^{[22]}$ The four cases that failed were due to infection, perhaps good infection control practices may further improve outcome. Interestingly, two case of failure each occurred in segmental and hemi-mandibulectomy defect respectively. Much has been documented on the role of defect size on outcome but the present review does not support this. Of note also is the fact that use of platelet rich plasma did not appear to improve success rate. This is despite the many documentation supporting its use as a bone graft enhancement.

In conclusion, use of NVICBG for immediate mandibular reconstruction appears to be associated with low complication and failure rates. Careful selection of patient, availability of adequate soft tissue cover, rigid fixation with the use of plates, tension free water tight soft tissue closure are factors that seem to contribute significantly to the success of grafting in use of NVICBG for mandibular reconstruction following ablative surgery for benign mandibular lesions.

\section{DECLARATIONS}

\section{Authors' contributions}

Concept and design, analysis and interpretation, writing and revision of manuscript and approved final draft: O.K. Ogundipe

Design, analysis and interpretation, writing and revision of manuscript and approved final draft: O.O. Gbolahan

\section{Financial support and sponsorship}

None.

\section{Conflicts of interest}

The authors declare that there are no conflicts of interest regarding the publication of this article.

\section{Patient consent}

Not applicable.

\section{Ethics approval}

Not applicable.

\section{REFERENCES}

1. Johannes TM, Robert JJ, Ellen M, Ron K. Non vascularized bone grat for segmental reconstruction of the mandible- a reappraisal. J Oral Maxillofac Surg 2009;67:1446-52.

2. Akinbami BO. Reconstruction of continuity defects of the mandible with non-vascularized bone grafts. Systematic literature review. Craniomaxillofac Trauma Reconstr 2016;9:195-205.

3. Agrawal A, Mehrotra D, Mohammad S, Singh RK, Kumar S, Pal US. Randomized control trial of non-vascularized fibular and iliac crest graft for mandibular reconstruction. J Oral Biol Craniofac Res 2012;2:90-6.

4. Hanasono MM. Reconstructive surgery for head and neck cancer patients. Adv Med 2014;2014:795483.

5. Akbay E, Aydogan F. Reconstruction of isolated mandibular bone defects with non-vascularized corticocancellous bone autograft and graft viability. Auris Nasus Larynx 2014;41:56-62.

6. Okoje VN, Obimakinde OS, Arotiba JT, Fasola AO, Ogunlade SO, Obiechina AE. Mandibular defect reconstruction with nonvascularized iliac crest bone graft. Niger J Clin Pract 2012;15:224-7.

7. Sándor GK, Tuovinen VJ, Patrikoski M, Lappalainen O, Seppänen R, Metinnen S. Adipose stem cell tissue-engineered construct used to treat large anterior mandibular defect: a case report and review of the clinical application of good manufacturing practice-level adipose stem cells for bone regeneration. J Oral Maxillofac Surg 2013;71:938-50.

8. Verrier S, Alini M, Alsberg E, Buchman SR, Kelly D, Laschke MW, Menger MD, Murphy WL, Stegemann JP, Schütz M, Miclau T, Stoddart MJ, Evans C. Tissue engineering and regenerative 
approaches to improving the healing of large bone defects. Eur Cell Mater 2016;32:87-110.

9. Hayden RE, Mullin DP, Patel AK. Reconstruction of the segmental mandibular defect: current state of the art. Curr Opin Otolaryngol Head Neck Surg 2012;20:231-6.

10. Mahajan A, Kashyap D, Singh B, Kumar A, Poonam. Scope of distraction osteogenesis in dentisrty - a mini review. J Regen Med Tissue Eng 2013;2:3.

11. Elsalanty ME, Genecov DG. Bone grafts in craniofacial surgery. Craniomaxillofac Trauma Reconstr 2009;2:125-34.

12. Faverani LP, Ramalho-Ferreira G, dos Santos PH, Rocha EP, Garcia Júnior IR, Pastori CM, Assunção WG. Surgical techniques for maxillary bone grafting - literature review. Rev Col Bras Cir 2014;41:61-7.

13. Wells MD. Mandibular reconstruction using vascularized bone grafts. J Oral Maxillofac Surg 1996;54:883.

14. Pogrel MA, Podlesh S, Anthony JP, Alexander J. A comparison of vascularized and nonvascularized bone grafts for reconstruction of mandibular continuity defects. J Oral Maxillofac Surg 1997;55:12006.

15. Moura LB, Carvalho PH, Xavier CB, Post LK, Torriani MA, Santagata M, Chagas Júnior OL. Autogenous non-vascularized bone graft in segmental mandibular reconstruction: a systematic review. Int J Oral Maxillofac Surg 2016;45:1388-94.

16. Tie Y, Wang DM, Ji T, Wang CT, Zhang CP. Three dimensional finite-element analysis investigating the biomechanical effects of human mandibular reconstruction with autogenous bone grafts. $J$ Craniomaxillofac Surg 2006;34:290-8.

17. Tidstrom KD, Keller EE. Reconstruction of mandibular discontinuity with autogenous iliac bone grafting: report of 34 consecutive patients. J Oral Maxillofac Surg 1990;48:336-46.

18. Ndukwe KC, Aregbesola SB, Ikem IC, Ugboko VI, Adebiyi KE, Fatusi OA, Owotade FJ, Braimah RO. Reconstruction of mandibular defects using nonvascularized autogenous bone graft in Nigerians. Niger J Surg 2014;20:87-91.

19. Olusanya AA, Aladelusi TO, Arotiba JT. Perioperative findings and complications of non-vascularised iliac crest graft harvest: the experience of a Nigerian tertiary hospital. Niger Med J 2014;55:2249.

20. Schimmele SR. Delayed reconstruction of continuity defects of the mandible after tumor surgery. J Oral Maxillofac Surg 2001;59:13404.

21. Lawson W, Loscalzo LJ, Baek SM, Biller HF, Krespi YP. Experience with immediate and delayed mandibular reconstruction. Laryngoscope 1982;92:5-10.

22. Baker A, McMahon J, Parmar S. Part I: Immediate reconstruction of continuity defects of the mandible after tumor surgery. $J$ Oral Maxillofac Surg 2001;59:1333-9.

23. Schlieve T, Hull W, Miloro M, Kolokythas A. Is immediate reconstruction of the mandible with nonvascularized bone graft following resection of benign pathology a viable treatment option? $J$ Oral Maxillofac Surg 2015;73:541-9.

24. Alfotawi R, Ayoub A. Reconstruction of maxillofacial bone defects: contemporary methods and future techniques. Am J Adv Med Sci 2014;2:18-27.

25. Goh BT, Lee S, Tideman H, Stoelinga PJ. Mandibular reconstruction in adults: a review. Int J Oral Maxillofac Surg 2008;37:597-605.

26. Obiechina AE, Ogunlade SO, Fasola AO, Arotiba JT. Mandibular segmental reconstruction with iliac crest. West Afr J Med 2003;22:469.

27. Futran ND, Urken ML, Buchbinder D, Moscoso JF, Biller HF. Rigid fixation of vascularized bone grafts in mandibular reconstruction. Arch Otolaryngol Head Neck Surg 1995;121:70-6.

28. Okoturo E. Non-vascularised iliac crest bone graft for immediate reconstruction of lateral mandibular defect. Oral Maxillofac Surg 2016;20:425-9.

29. Simon EN, Merkx MA, Kalyanyama BM, Shubi FM, Stoelinga PJ. Immediate reconstruction of the mandible after resection for aggressive odontogenic tumours: a cohort study. Int J Oral Maxillofac Surg 2013;42:106-12.

30. Shirani G, Arshad M, Mohammadi F. Immediate reconstruction of a large mandibular defect of locally invasive benign lesions (a new method). J Craniofac Surg 2007;18:1422-8.

31. Anjum S, Khan NA, Ahmad M. Treatment outcomes of reconstruction with iliac bone graft and rib graft in patients with mandibular defects. Pakistan Oral Dent J 2013;33:423-5.

32. Benson PD, Marshall MK, Engelstad ME, Kushner GM, Alpert B. The use of immediate bone grafting in reconstruction of clinically infected mandibular fractures: bone grafts in the presence of pus. $J$ Oral Maxillofac Surg 2006;64:122-6.

33. Mooren RE, Hendriks EJ, van den Beucken JJ, Merkx MA, Meijer GJ, Jansen JA, Stoelinga PJ. The effect of platelet-rich plasma in vitro on primary cells: rat osteoblast-like cells and human endothelium cells. Tissue Eng 2010;16:3159-72.

34. Kumar KA, Rao JB, Pavan Kumar B, Mohan AP, Patil K, Parimala K. A prospective study involving the use of platelet rich plasma in enhancing the uptake of bone grafts in the oral and maxillofacial region. J Maxillofac Oral Surg 2013;12:387-94.

35. Magesh DP, Kumaravelu C, Maheshwari GU. Efficacy of PRP in the reconstruction of mandibular segmental defects using iliac bone grafts. J Maxillofac Oral Surg 2013;12:160-7.

36. Matsuo A, Chiba H, Takahashi H, Toyoda J, Hasegawa O, Hojo S. Bone quality of mandibles reconstructed with particulate cellular bone and marrow, and platelet-rich plasma. J Craniomaxillofac Surg 2011;39:628-32.

37. Suryanarayan S, Budamakuntla L, Khadri SI, Sarvajnamurthy S. Efficacy of autologous platelet-rich plasma in the treatment of chronic nonhealing leg ulcers. Plast Aesthet Res 2014;1:65-9. 